\title{
Optogenetik ve Beslenme
}

\section{Optogenetics and Nutrition}

\author{
Esra Fidan ${ }^{1}$, Zülfikare Işık Solak Görmüş²
}

${ }^{1}$ Konya Numune Hastanesi, Beslenme ve Diyet Birimi, Konya, Türkiye

${ }^{2}$ Necmettin Erbakan Üniversitesi, Meram Tıp Fakültesi, Fizyoloji Anabilim Dalı, Konya, Türkiye

Yazışma Adresi: Esra Fidan, Konya Numune Hastanesi, Beslenme ve Diyet Birimi, Konya, Türkiye

e-posta: esrafidan1990@gmail.com

Geliş Tarihi/Received: 26 Mayıs 2021 Kabul Tarihi/Accepted: 2 Eylül 2021

\section{Öz}

Optogenetik, beyindeki belirli nöron gruplarını açmak veya kapatmak için ışığı kullanan biyolojik bir tekniktir. Optogenetiğin avantajı, hücre özgüllüğünün olmasıdır. Bu şekilde belirli nöron grupları hedeflenebilir ve tüm fonksiyonları incelenebilir. Optogenetikte ışık bir nöronun fonksiyonunu oluşturan elektirik potansiyellerine dönüştürülerek, opsin adı verilen proteinlere sahip spesifik nöronlara yüklenir. Beynin belirlenen bölgesine ışık tutulduğu zaman, sadece opsin yüklü nöronları aktive olur ve bu şekilde istenen potansiyel oluşturulur. Optogenetiğin ilk çalışmaları, beyne optik fiberler aracılığıyla ışık gönderilmesi, bu şekilde deneklerin fiziksel olarak bir kontrol istasyonuna bağlı olması seklindedir. Sonraki zamanlarda araștırmacılar, kablosuz elektroniği kullanarak pilsiz bir teknikle deneklerin serbestçe hareket edebilmesini sağlamış. Ancak bu cihazlar büyük hacimli ve sıklıkla kafatasının dışına görünür bir şekilde tutturulmaları, ışığın frekansının veya yoğunluğunun hassas bir şekilde kontrol edilmesine izin vermeyişleri ve bir seferde beynin sadece bir bölgesini uyarabilmeleri nedeniyle kullanılmaları zor olmuştur. Işığın beynin hangi alanını seçeceği, ısığın yoğunluğunun kontrolü, ışık kaynakları tarafından üretilen ısı ile harekete geçen nöronların yanlışlıkla aktifleştirilmesinin önlenmesi çalışmalar açısından önem arz etmektedir. Optogenetik yöntemlerin gelişimi birçok hastalığın tanı ve tedavi yöntemlerinin fotonlarla sağlanabilmesini kolaylaştıracaktır. Optogenetik yöntemle beslenme ile ilgili beyin bölgelerinde yapılan çalışmalar beslenme bozukluklarının (hiperfaji, anoreksi vb.) tedavisi açısından da oldukça önemlidir.

Anahtar Kelimeler: Optogenetik, opsin, nöron.

\section{Abstract}

Optogenetics is a biological technique that uses light to turn on or turn off certain groups of neurons in the brain. The advantage of optogenetics is that it has cell specificity. In this way, certain groups of neurons can be targeted and all their functions can be examined. In optogenetics, light is transformed into electrical potentials that form the function of a neuron and loaded onto specific neurons with proteins called opsin. When light is shined on the designated area of the brain, only opsin-loaded neurons are activated, and in this way the desired potential is created. The first studies of optogenetics were sending light to the brain through optical fibers, so that the subjects were physically connected to a control station. Later, researchers used wireless electronics to allow subjects to move freely with a battery-free technique. However, these devices have proved difficult to use because they are large in volume and often attached to the outside of the skull visibly, do not allow precise control of the frequency or intensity of light, and can only stimulate one area of the brain at a time. Which area of the brain the light will select, the control of the intensity of the light, and the prevention of accidental activation of the neurons that are activated by the heat produced by the light sources are important for studies. The development of optogenetic methods will make it easier to provide diagnosis and treatment methods of many diseases with photons. Studies in brain regions related to nutrition by optogenetic method are also very important in terms of treatment of nutritional disorders (hyperphagia, anorexia, etc.).

Key words: Optogenetics, opsins, neurons.
Atıf yapmak için: Fidan E, Solak Görmüş ZI. Optogenetik ve Beslenme. Selcuk Med J 2021;37(3): 287-293
Açıklama: Yazarların hiçbiri, bu makalede bahsedilen herhangi bir ürün, aygıt veya ilaç ile ilgili maddi çıkar ilişkisine sahip değildir. Araştırma, herhangi bir dış organizasyon tarafından desteklenmedi. Yazarlar çalışmanın birincil verilerine tam erişim izni vermek ve derginin talep ettiği takdirde verileri incelemesine izin vermeyi kabul etmektedirler. 


\section{OPTOGENETIK NEDIR?}

Optogenetik, genler üzerinde bulunan ya da yerleştirilen ışığa duyarlı araçlarla canlı doku ve hücrelerde hücresel aktivitelerin izlenmesi ve yönlendirilmesi amacıyla kullanılan optik ve moleküler sistemlerden oluşan bir bilimdir (1). Bu sistemde ışık kullanılarak hücreler arası elektiriksel iletim, hücre hareketleri, protein ve organellerde moleküler ve hücresel süreçlerin denetlenmesi ve dönüştürülmesine imkan sağlanmaktadır (2). Beynin otonom düzenleme alanlarıyla yapılan çalışmalarda kullanılan optogenetik, fenotipik olarak belirlenen nöron gruplarını ve astrositleri aktive ederek ya da inaktive ederek etkide bulunmaktadır (3).

\section{TARIHİ, UYGULAMAYÖNTEMLERI VE SISTEMLERİ}

Beyindeki nöron grupları ve astrositlerin bir grubunu seçici olarak ışık etkisiyle kontrol etme fikri Francis Crick isimli araştırmacı tarafından 1999'da ortaya atılmıştır. Ancak bu konuya dair anlamlı bir çalışma birkaç yıl sonra Boris Zemelman ve Gero Miesenböck isimli araştırmacılar tarafından ortaya konmuştur. Yapılan çalışmaya göre meyve sineğine (drozofila) ait ışık reseptörleri memeli hayvanlara ait bir sinir hücresi kültürüne yerleştirilmiş ve sinir etkinliği kontrol edilmiştir (4). Optogenetik deneylerde opsin (bakteriyorodopsin, kanalrodopsin, halorodopsin ve genetik olarak kodlanmış optik aralar) olarak adlandıılan, ışığa duyarlı proteinler kullanılmaktadır. Daha sonraları sinir sistemlerindeki nöronları aktifleştirmek (ChR1, ChR2, VChR1 ve SFO nöronları) ya da pasifleştirmek (NpHR, eNpHR2.0, eNpHR3.0 ve Arch) için kullanılabilecek çok sayıda opsin molekülleri bulunmuştur $(5,6)$. Bu moleküller ışık etkisiyle hücre zarından iyon translokasyonunu sağlamaktadır. Dolayısıyla bu molekülleri spesifik hücrelere aktarmak, ışıkla uyarı sağlamak ve canlı dokularda elektiriksel ve biyokimyasal süreçlere etkide bulunmak mümkün olabilmektedir. Bu sistemde opsin proteinin ancak özgün nöron ortamlarındayken işlev gösterebildiği düşünülmekteydi. Örneğin önceleri halorodopsinlerin yalnızca yüksek tuzlu ortamda etkinlik gösterebildiği düşünülürken, 1999 yılında yapılan bir çalışmada bir tür halorodopsinin (Natronomonas pharaonis) yüksek seviyedeki klor iyonu ortamında da iyi bir biçimde iyon pompalama işlevini yerine getirebildiği gözlenmiştir (5).

Özel bir nörostimülasyon (bir nöron hücresinin suni yöntemle uyarılması) yaklaşımı olan 'fotostimülasyon' kavramı 2001 yılında gündeme gelmiştir. Optogenetik alanında kullanılan fototetikler şu şekilde sıralanabilir.

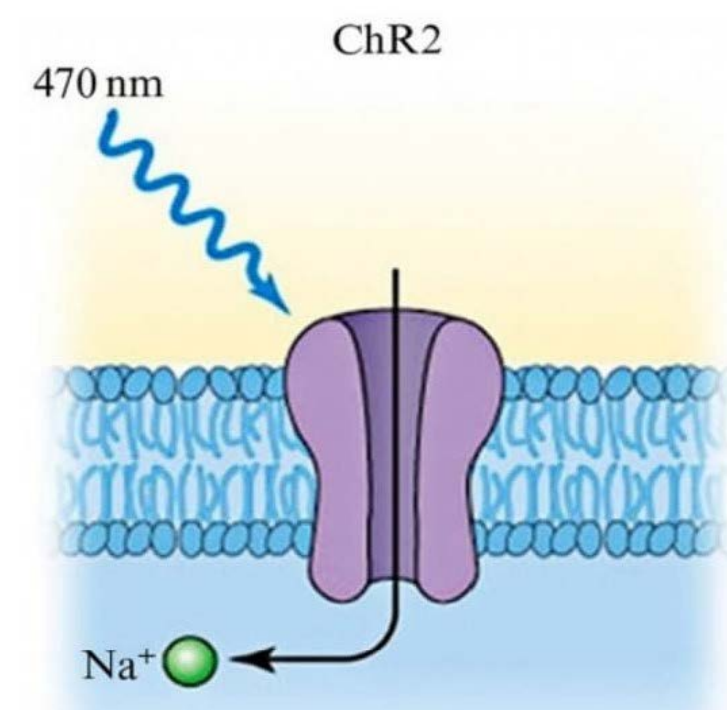

Şekil 1a. Kanalrodopsin Fototetik Mekanizması (8)

\section{a) Bakteriyorodopsin:}

Yeşil alglerde bulunan yeşil ışığa duyarlı, hücre içine katyon girişini sağlayan ve transfekte edildiği nöron hücresinde aksiyon potansiyeli oluşumunu destekleyen opsin türüdür (7).

\section{b) Halorodopsin (NpHR):}

Halobacterium salinarum'da bulunan, sarı ışığa duyarlı opsin türüdür (Şekil $1 \mathrm{~b}(8)$ ). Cl- iyonlarının hücre içine girişini kolaylaştırarak hücre membran potansiyelini azaltıp aksiyon potansiyelinin oluşumunu engellemektedir (7).

\section{c) Kanalrodopsin (ChR):}

Yeşil yosunlarda (Chlamydomonas reinhardtii) bulunan ve mavi ışığa duyarlı opsin türüdür (Şekil 1a (8)). Işıkla uyarıldığında hücre içine $\mathrm{Na}+$ girişini artırarak aksiyon potansiyelini kolaylaştırmaktadır (7).

\section{d) Genetik Kodlu Optik Araçlar (OptoXR):}

Rodopsinin (gözde bulunan ve karanlıkta görmeyi sağlayan protein) transellüler parçasının diğer reseptörlerin hücre içi parçaları ile değiştirilmesi ile geliştirilen reseptörlerdir. Bu şekilde birbirinden farklı bölgelerdehücreleriaktiveyadainhibeedilebilmektedir. OptoXR geni, rodopsini aktifleştirerek, görmede etkili olan reseptörlerin geliştirilmesini sağlamaktadır (7). İn vivo uygulama esnasında hedef bölge derin beyinde ise, ışığı hedeflenen beyin bölgesinin iletebilmek için optik fiberlerin yerleştirilmesi gerekir. Eğer hedeflenen 


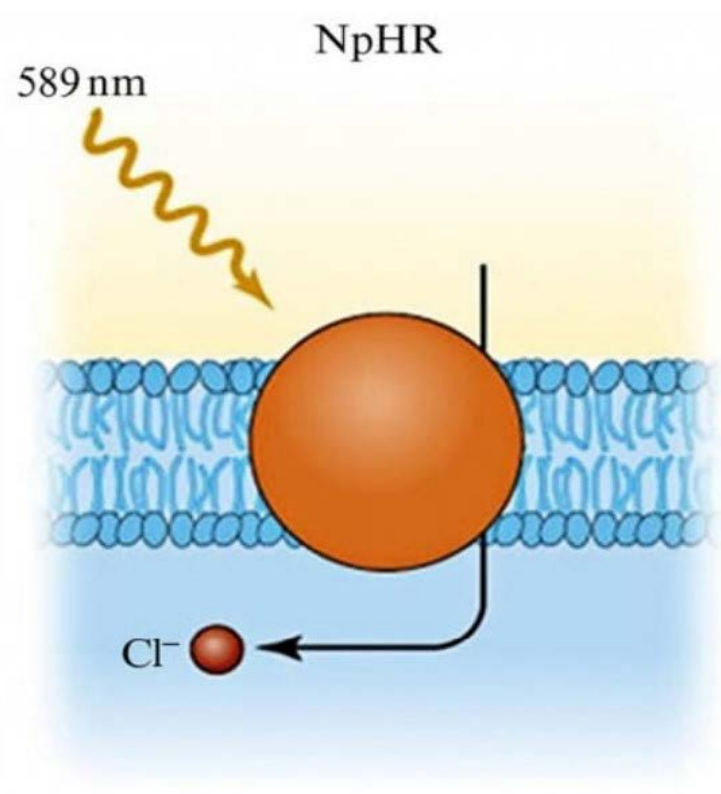

Şekil 1b. Halorodopsin Fototetik Mekanizması (8)

nöron derin beyinde ise optik fiber sistemleri dokuya zarar verme ve hayvan davranışını etkileyebilme etkisi nedeniyle invaziv araçların yokluğunda spesifik bölgeye ışığı iletmek zorlaşmaktadır. Gong et al. elektrot ve kablo kullanım zorluğuna karşılık derin beyindeki nöronların invazif işlemler olmadan uyarılmasını sağlayacak, özellikle de düşük seviyedeki ışık etkisinde bile duyarlı olan yeni bir opsin türü (stepfunction opsin with ultra-high light sensitivity- SOUL) keşfetmiştir. SOUL geni etkinleştirildiğinde diğer opsinlere göre daha uzun süre aktif kalabilmektedir. Bu etki birkaç saniyelik düşük seviyeli ışık patlamasında dahi nöronların 10-30 dakika aktif kalmasının sağlanabilmesi anlamına gelmektedir. Gong et al. (9) laboratuvarda SOUL geniyle oluşturulan iyon kanalını fare beyninin lateral hipotalamusunda ifade etmiş, ışıkla bu bölgeyi invaziv işlem uygulamadan uyarmış ve farelerin beslenmesinde değişiklikler meydana getirebilmişlerdir.

Opsinler optogenetik çalışmalarda kullanılabilmek için öncelikle deney yapılacak hayvanın beyninde belirlenen nöronlara aktarılmalıdır. $\mathrm{Bu}$ işlemin gerçekleştirilebilmesi için bilinen iki yöntemden biri, genetiği değiştirilen virüslerdir. Virüsler genlerini temas ettikleri hücrelere aktarabilen özel moleküler mekanizmaları sayesinde bu işlemi gerçekleştirmede etkindirler. İstenilen opsin türünün üretilebilmesi

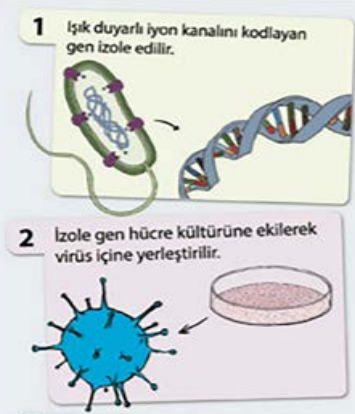

3 Virüs enjekte edilerek hedef bölgenin

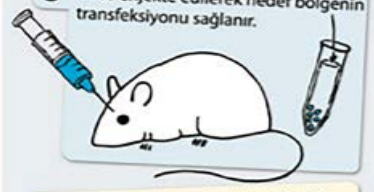

4 F

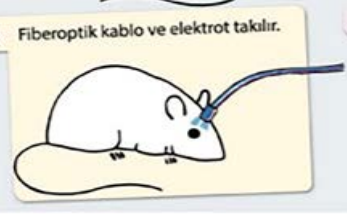

5 Aydinlatma sonucunda

yon kanali açlitr.

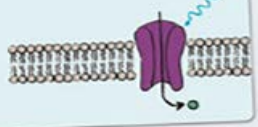

6 Alsiyon potansiyeli olusur.

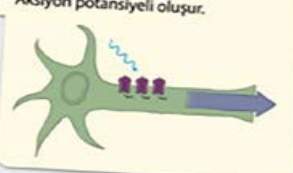

7 Elektrofizyolojik degigiklikler kaydedili:

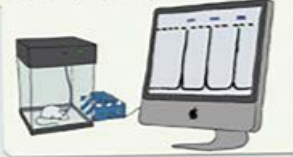

8 Davranus değisjiklikjleri gözlemlenir.

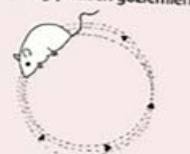

Şekil 2. Optogenetik Uygulama (10)

için belirlenen genler virüsün genomuna yüklenir ve virüs canlının vücuduna aktarılır. Virüsün genleri hedeflenen nöronlara aktarması ve istenen opsinin bu hücrelerde üretilmesi sağlanır. Genin aktarımı için diğer yöntem ise transgenik canlılar (örneğin fareler) kullanılarak gerçekleştirilir (Şekil 2 (10)).

$\mathrm{Bu}$ yöntemde opsin proteinlerinin üretilmesini sağlayacak genler ratların zigotlarına yerleştirilir ve yavruların nöronlarında opsinlerin üretilmesi sağlanır (5). Belirlenen opsine ait genlerin istenilen dokuya transfeksiyonu için öncelikle gen hedeflenir. Bu genin birkaç nükleik asitlik bölümünün bilinmesi gerekir. Amaçlanan genin translasyon ürünü olan mRNA izole edilir ve ters transkriptaz enzimi ile elde edilen cDNA izolasyonu sonrasında polimeraz zincir reaksiyonu (PCR) tekniği ile genin çoğaltılma işlemi gerçekleştirilir. Genin vektöre aktarılma işlemi için elektroporasyon tekniği (hücrelere veya dokulara kısa süreli cok kuvvetli elektirik akımı uygulanarak, hücre zarında nanometre boyutunda geçici porlar oluşturma işlemi) kullanılır ve izole edilen genin hücre kültür ortamına ekimi yapılır. Sterotaksik yöntemlerle ilgili bölgeye fiber optik kablo ve elektrot takıldıktan sonra aydınlatma etkisiyle iyon kanalları açılır ve aksiyon potansiyeli oluşturulur. Hücrelerin zarlarında oluşan geçici porlar aracılığıyla DNA, enzim ve diğer moleküllerin intraselüler ortama girişi sağlanmış olur 


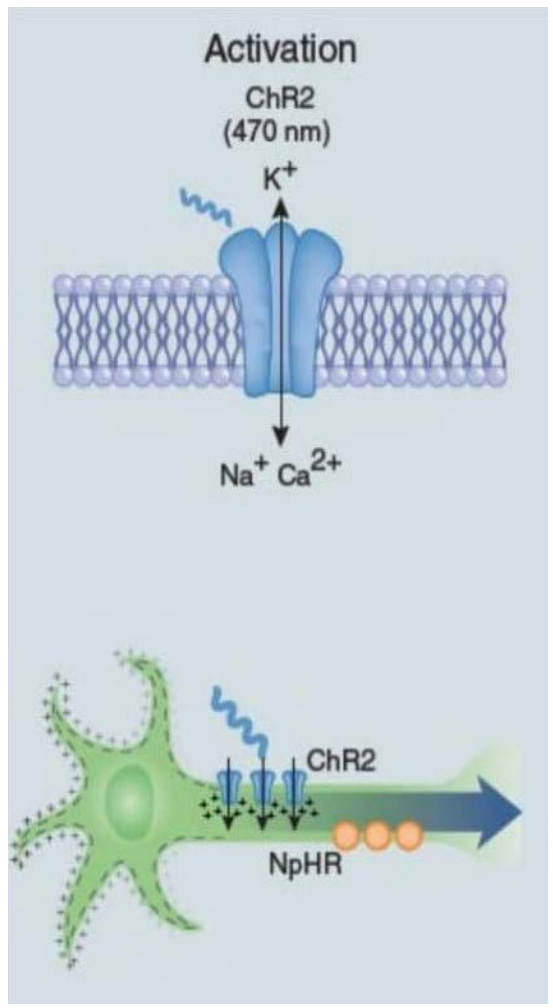

Şekil 3a. Fototetik kanalrodopsin iyon kanalları aracılığıyla aksiyon potansiyeli oluşumu (8)

(7), (Şekil 3a-3b(8)).

\section{BESLENME VE OPTOGENETIKK İLIŞKISi}

Açlık ve tokluk arasındaki değişime aracılık eden parametrelerin yavaş iletimi homeostatik gıda alım mekanizmalarını incelemeyi zorlaştırmaktadır. Besin arama ve tüketim davranışını yönlendirmek için hormonların çevre dokulardan salınması, beyne iletilmesi ve besin algılayıcı nöronlara sinyal göndermesi gerekir. Bunun için, moleküler olarak sınırlandırılmış besin algılayıcı nöronların manipülasyonları, beslenmenin merkezi kontrolünü sağlamak için kullanılabilir (11). Hipotalamusun arkuat çekirdeği (ARC), beynin tabanında üçüncü ventrikül ve medyan eminensin üstüne bitişik pozisyondadır ve periferik dokulardan dolaşım yoluyla taşınan sinyalleri entegre etmektedir. ARC alt popülasyonlarından oreksijenik agouti ile ilişkili protein (AgRP) ve anoreksijenik propiomelanokortin (POMC) nöronları, gıda alımındaki değişikliklerle ilişkilidir $(12,13)$. AgRP nöronları tarafından salınan nöromodülatörler (GABA ve nöropeptid $Y$ ) gıda alımını

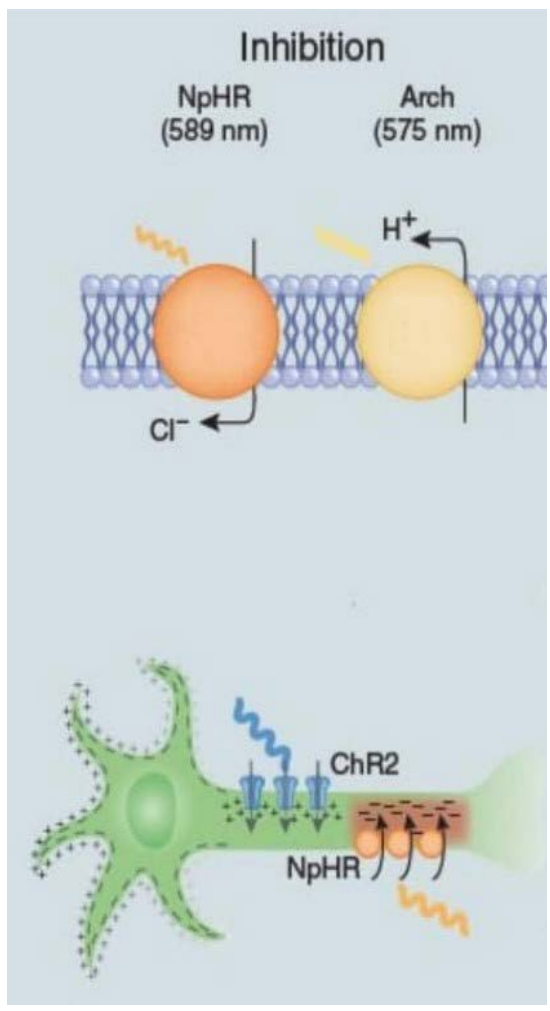

Şekil 3b. Fototetik halorodopsin ve Archarodopsin iyon kanalları aracılığıyla aksiyon potansiyeli oluşumu (8)

akut teşvik ederek beslenmeyi artırırken, $\alpha$-melanosit uyarıcı hormon ( $\alpha-\mathrm{MSH})$, adrenokortikotrofik hormon (ACTH) ve POMC nöronları besin alımını azaltan kronik düzenlemeden sorumludur $(14,15)$. Her iki heterojen alt tip, enerji sinyalleri veren glikoz, insülin ve leptin hormonu tarafından inhibe edilirken, ghrelin hormonu tarafından aktive edilir $(14,15)$. AgRP nöronlarının optogenetik veya kemogenetik (ilaç verilerek) aktivasyonu, açlık algısının oluşmasına ve buna bağlı olarak da aşırı bir besin alımına neden olmaktadır. Besin tüketiminin derecesi ise hem uyarılabilir nöronların sayısından hem de uyarılma frekansından etkilenmektedir (14). Bu nöronların kronik aktivasyonu sonucunda oluşan hiperfaji ve azalan enerji harcaması, yağ depolarının artışıyla beraber aşırı kilo alımına yol açabilir. Normal bir dinlenme döneminde, yiyecek yokluğuyla akut olarak uyarılmış AgRP nöronlarına sahip hayvanlar, yiyecek varlığında tamamen tersine dönen yoğun şekilde lokomotor aktivite sergiler ve bu nöronlar yiyecek arama işlevini artırır (15). Enerji homeostazını 
korumak için oreksijenik ve anoreksijenik beyin sistemleri, gıda alımını düzenlemek için işlevsel olarak etkileşime girer. AgRP oreksijenik faktörleri algılar ve yiyecek arama davranışında bir artışı tetikler. Bunun aksine, parabrakial çekirdekte (PBN) kalsitonin geni ile ilişkili peptit (CGRP) nöronlar beslenmeyi baskılar. PBN CGRP nöronları, pankreas tarafından salgılanan amilin ve ince bağırsak tarafından salgılanan kolesistokinin (CCK) dahil olmak üzere bir yemekten sonra salınan anoreksijenik hormonlara yanıt olarak aktifhale gelir. AgRP nöronlarının enflamatuarolmayan iştah bastırma sırasında beslenmeyi arttırmak ve anoreksijenik PBN' daki CGRP nöronlarındakiaktiviteyi azaltmak ve böylece homeostatik intiyaç sırasında gıda alımını arttırmak için yeterli olduğu bilinmektedir (16). GABAerjik projeksiyonların oreksijenik yönde optogenetik uyarımı, doymuş farelerde beslenme davranışını ve belirlenen yiyecek bölgesinde geçirilen zamanı artırırken, bu projeksiyonların anoreksijenik yönde uyarımı, fareler aç olsa dahi beslenmeyi azaltmaktadır (17).

Dorsamedial hipotalamusdaki (DMH) kolinerjik nöronların besin alımı üzerindeki rolüne ilişkin yapılan bir çalışmada; DMH kolinerjik nöronları seçici olarak uyarmak için kolin asetiltransferaz IRES-Cre (CHAT geni bulunan) farelerine adeno bağlantılı virüs vektörleri ya da uyarıcı düzenleyici ilaçlar (kemojenetik etki) vasıtasıyla kanalrodopsin reseptörleri açığa çıkarılmış. Sonuçta DMH da CHAT geninden yoksun farelerin sağlıklı farelere kıyasla daha düşük vücut ağırlığına sahip olduğu bulunmuştur. Bu durumun DMH kolinerjik nöronların kemojenetik aktivasyonunun ve optogenetik uyarımının oreksijenik etkiyi teşvik etmesi nedeniyle oluştuğu düşünülmüştür. $\mathrm{DMH}$ kolinerjik nöronlardan salınan asetilkolin presinaptik muskarinik reseptörlerin aktivasyonu yoluyla hipotalamusun arkuat çekirdeğindeki (ARC) propiomelanokortin nöronlarında GABAerjik inhibitör etkiyi güçlendirerek innerve etmektedir. Doğrudan DMHACh / ARCPOMC yolunun aktivasyonu, gıda alımının ve vücut ağırlığının artışında etkin bir rol oynamaktadır (18). Açlığın bilişsel fonksiyonlar üzerindeki etki mekanizmasını hücresel düzeyde inceleyen bir araştırmacı AgRP nöronlarının öğrenme ve bellek üzerindeki davranışsal etkilerini gözlemlemeyi amaçlamıştır. Oluşturduğu gruplardan optogenetik uyarıda bulunacağı grubu ve kontrol grubunu serbest beslenme ile beslemiş, bir grubu da 18 saat boyunca beslememiştir. Grupları su labirenti testinde öğrenme kapasiteleri ve hafıza performansları yönünden kıyaslamış, optogenetik uyarı grubunun platforma ulaşma zamanının, kontrol grubuna göre anlamlı şekilde kısaldığını gözlemlemiştir. Sonuç olarak da AgRP nöronlarının optogenetik yolla spesifik uyarılmasının öğrenme kapasitesini geliştirdiğini düşünmüştür (7).

Hayvanlar dışsal uyaranlardan öğrendikleriyle tahmin etme yeteneği kazanırlar. Ayrıca iç durumlarıyla ilgili periferik sinyaller (örneğin açlık) mevcut ihtiyaçlarla ilgili bilgi oluşumuna ve yiyecek arama davranışına yönlendirilmesini modüle eder (19). Yapılan bir çalışmada amigdala'nın (CeA) merkez çekirdeğindeki nöronların optogenetik kanalrodopsin stimülasyonunun, sıçanlarda belirli bir sükroz ödülü kazanma gibi tek ödül hedefine yönelik teşvik motivasyonunu güçlendirdiğini ve daralttığını rapor etmiştir. CeA fareleri, eşit derecede iyi bir sükroz alternatifini görmezden gelirken yalnızca lazerle eşleştirilmiş sükroz ödülünü yoğun bir şekilde takip ederek onu seçmişlerdir. Aynı sonuç bazolateral amigdala uyarılarak denendiğinde elde edilememiştir. CeA uyarımı tek başına, herhangi bir eşleştirilmiş gıda ödülünün yokluğunda davranışsal uyarımı desteklemede başarısız olmuştur (20). Yakın zamanda yapılan bir öğünün kalıcı bellek kaydı sonraki yemeyi sınırlandırır, ancak hatırayı anımsatıcı etkilerin altında yatan sinirsel mekanizmalar tam olarak bilinmemektedir. Viral vektör yerleştirilerek yapılan bir araştırmada, sükroz veya sakarin içeren yemeğin bitimiyle yemek hafızası konsolidasyona (hatıraların erişilebilir hale gelme süreci) uğraktan sonra, dorsal hipokampal (dHC) veya ventral hipokampal (vHC) glutamaterjik piramidal nöronların optogenetik inhibisyonu sonrasında bir sonraki öğün sıklığının azalttığı ve öğünde tüketilen miktarı artırdığı gözlenmiştir. Bu bulgular, ana hipokampal nöronların sonraki alımı sınırladığını ve bunu önceki öğünün hafızasını pekiştirerek yaptıklarını göstermektedir (21).

Lateral hipotalamus (LH), 60 yılı aşkın süredir gıda alımı ve ödül arama motivasyonu için güçlü bir düzenleyici olarak kabul edilmektedir. Günümüzde LH obezite, iştahsızlık ve ödülle ilgili motivasyonel işlev bozuklukları konusundaki araştırmaların birincil hedefi olmaya devam etmektedir. Kendi kendine uyarımı desteklemek ve yemede lazere bağlı artışları belirlemek üzere $\mathrm{LH}$ alt bölgelerinin etkilerinin gözlemlenmesi amacıyla yapılan bir çalışmada; tüberal LH'nın tekrarlanan stimülasyondan sonra kendi kendine teşvik edici stimülasyon davranışına doğru kaydığı, lateral preoptik alan ve posterior LH bölgelerininse ne yeme davranışını, ne de lazerin kendi kendine stimülasyonunu belirgin olarak ortaya 
çıkarmadığı ancak daha yüksek yoğunluklu etkilere yanıt oluşturabildiği görülmüştür. $\mathrm{Bu}$ sonuçlar aynı zamanda optogenetik LH stimülasyonunun davranışsal etkilerinin esnekliğe sahip olduğu ve aynı kişide uzun süreli lazer stimülasyonunun zamanla davranışsal etki oluşturabileceğini göstermektedir (22).

\section{DíĞER KULLANIM ALANLARI}

Optogenetik nöron aktivitesini manipüle etme, belirli nöronların işlevinin düzenlenmesi ve nörolojik bozukluklarda semptomların azaltılması açısından terapötik potansiyel göstermektedir (23). Korku ile ilişkili davranış süreçlerinin mekanizmalarını belirleme hususunda optogenetik çalışmalar oldukça etkilidir. Doğuştan gelen korkuların altında yatan nöron devrelerinin çalışmasını ve birbirleriyle etkileşimlerinin tanımlanmasını sağlamaktadır. Bu şekilde aşırı korku modüle edilebilmekte veya tedavi edilebilmektedir (24). Lima ve Miesenbock'ın dopaminerjik sinir hücreleri üzerine yapmış oldukları fotostimülasyon çalışması, optogenetik davranış çalışmalarının ilki olarak kabul edilir. Bu çalışmada drosophila'lara P2X2 kanalları transfekte edilmiş. Işıkla aktive olan paket adenozin molekülleri aracılığıyla açılan iyon kanallarından $\mathrm{Ca}+2$ iyon geçişi ve aksiyon potansiyeli oluşturulmuş ve davranışsal bir etki oluşturulmuştur. Drosophila'ların hareket kalıplarını değiştirerek daha korkusuz davrandıkları belirlenmiştir (4). Massachusetts Teknoloji Enstitüsü'nde yapılan bir çalışmaya göre optogenetik yöntemlerle farelerin hafızalarına yanlış anılar depolanması başarılmıştır. Çalışmada ilk olarak bir fare daha önce görmediği siyah zeminli, loş kırmızı ışık ve asetik asit kokusu bulunan bir kafesin içine bırakılmış ve ortamı keşfetmesi beklenmiş. Ertesi gün fare renklerin, ışıkların ve kokuların tamamen farklı olduğu başka bir kafese konmuş ve ayaklarına hafif elektirik şoku uygulanmış. Bu sırada farenin beynine bağlanan optik fiberler üzerinden hipokampüsüne mavi ışık gönderilerek bir önceki gün fare ilk kafesi keşfederken etkinleşen nöronlar uyarılmış, böylece farenin elektirik şoku deneyiminden ziyade hiç acı hissetmediği ilk kafesteki anılarının aktifleşmesi sağlanmış (25).

Alzheimer, sinirsel faaliyetleri birçok düzeyde etkileyen nörodejeneratif bir bozukluktur. Optogenetik araçlarla sinaptik molekülleri uyararak Alzheimer modellerindeki yapısal bozulmaları ortaya çıkarmak, Alzheimer'ın neden olduğu öğrenme ve hafıza kaybını önleyebilmek mümkün görünmektedir (23). Elektronik cihazların kullanımına bağlı kalp aktivasyonunda meydana gelen aritmilerin düzenlenmesi ve ani kalp ölümü riskinin azaltılması optogenetik yöntemlerle mümkündür (26). Defibrilasyon (ışık temelli elektro şok cihazı) stratejilerini optimize etmekte elektiriksel aktiviteyi saptamak ve uyarmak için geliştirilmiş optik elektrofizyolojik yöntemler, nöronun kendine özgü uyarılabilirliği ve sinaptik iletim üzerindeki etkilerini değerlendirmek için de kullanılabilmektedir (27). Ayrıca optogenetik kalp pilleri ve kalsiyum ile kombine ilaç etkilerinin insan kalp aktivitesi üzerindeki etkilerini araştırmak için önemli bir katkı sağlamaktadır (28).

Fare modellerinde yapılan bir çalışmada premotor korteksin kanalrodopsin fototetik mekanizmalarının uyarımıyla, akson miyelin kalınlığı ve oligodendrosit çoğalması üzerinde pozitif etkileri olduğu tespit etmişlerdir (29). Periferik sinir sistemi üzerine yapılan çalışmalarda motor kontrol, ağrı ve somatosensöriyel transdüksiyon üzerinde optogenetiğin anlamlı etkilerinin olduğu belirlenmiştir (30).

\section{DEĞERLENDIRME}

Obez insanlar bir uyuşturucu bağımlısının uyuşturucuya karşı bırakma stratejisi geliştirebildiği gibi, yiyeceklerden tamamen kaçınmak için stratejiler geliştiremezler. Hayatta kalmak için yemek gereklidir ve bu durum potansiyel tedavileri düşünürken beslenmenin uyarlanabilir ve uyarlanamaz bileşenlerini ayrıştırmayı zorlaştırır. Beslenme davranışlarının hem hayatta kalmak için gerekli, hem de aşırı derecede zararlı olma yeteneği göz önüne alındığında, gıda bağımlılığıyla ilgili sinir devrelerini anlamak, optogenetik ve kemogenetik yaklaşımlarla kolaylaştırılan manipülasyonlargibi son derece hassas araçlar gerektirmektedir. Optogenetik yöntemlerin gelişimi birçok hastalığın tanı ve tedavi yöntemlerinin cerrahi işlemler uygulanmadan ışı sistemiyle sağlanabilmesini kolaylaştıracaktır. Optogenetik yöntemle beslenme ile ilgili beyin bölgelerinde yapılan çalışmalar beslenme bozukluklarının (hiperfaji, anoreksi vb.) tedavisi açısından geleceğe ışık tutmaktadır.

Çıkar Çatışması: Çalışmada herhangi bir çıkar çatışması yoktur.

Finansal Çıkar Çatışması: Çalışmada herhangi bir finansal çıkar çatışması yoktur.

Yazışma Adresi: Esra Fidan, Konya Numune Hastanesi, Beslenme ve Diyet Birimi, Konya, Türkiye e-mail: esrafidan1990@gmail.com 


\section{KAYNAKLAR}

1. Beyaz S, Aslan A. Optogenetik. Fırat Üniversitesi, Fen Fakültesi, Biyoloji Bölümü Moleküler Biyoloji ve Genetik Programı, Elazığ, 2018. https://dergipark.org.tr/tr/pub/ yyufbed/issue/39163/432910.

2. Liu Q, Tucker QC. Engineering genetically-encoded tools for optogenetic control of protein activity. Curr Opin Chem Biol 2017;40:17-23.

3. Kasparov S.Optogenetics. In: Low PA, ed. Primer on the autonomic nervous system. 3rd ed. Cambridge: Academic Press 2012:689-91.

4. Zemelman BV, Miesenböck G. Genetics chemes and schemata in neurophysiology. Curr Opin in Neurobiol 2001;11(4):409-14.

5. Ocak ME. Optogenetik. TÜBITAK Bilim ve Teknik Dergisi 2017:38-43.

6. Gradinaru V, Thompson KR, Deisseroth K. eNpHR: A natronomonas halorhodopsin enhanced for optogenetic applications. Brain Cell Biol 2008;36:129-39.

7. Alp Mi. Açlık kuramına yeni bir bakış: Arkuat çekirdeğin optogenetik olarak uyarılmasının kognitif davranış üzerine etkisi. Selçuk Üniversitesi, Sağlık Bilimleri Enstitüsü, Doktora Tezi, Konya, 2017.

8. Pastrana E. Optogenetics: Controlling cell function with light Nat Meth 2011;8:24-25.

9. Gong X, Mendoza-Halliday D, Ting JT, et al. An ultra-sensitive step-function opsin for minimally Invasive optogenetic stimulation in mice and macaques. Neuron 2020;107:38-51.

10. Alp Mi, Demir EA, Gergerlioğlu HS. Optogenetiğin temelleri. Eur J Basic Med Sci 2014;4(2):37-43.

11. Sternson SM. Hypothalamic survival circuits: Blue prints for purposive behaviors. Neuron 2013;77:810-24.

12. Cowley MA, Smith RG, Diano $S$, et al. The distribution and mechanism of action of ghrelin in the CNS demonstrates a novel hypothalamic circuitregulating energy homeostasis. Neuron 2003;37:649-61.

13. van den Top $M$, Lee $K$, Whyment $A D$, et al. Orexigen- sensitive NPY/AgRP pacemaker neurons in the hypothalamic arcuate nucleus. Nat Neurosci 2004;7:493-4.

14. Aponte Y, Atasoy D, Sternson SM. AgRP neurons are sufficient to orchestrate feding behavior rapidly and without training. Nat Neurosci 2011;14:351-5.

15. Krashes MJ, Koda S, Ye C, et al. Rapid, reversible activation of AgRP neurons drives feding behavior in mice. J Clin Invest 2011;121:1424-8.

16. Essner RA, Smith AG, Jamnik AA, et al. AgRP neurons can increase food intake during conditions of appetite suppression and Inhibit anorexigenic parabrachial neurons. J Neurosci 2017;37(36):8678-87.
17. Krashes MJ, Shah BP, Koda S, et al. Rapid versus delayed stimulation of feding by the endogenously released AgRP neuron mediators GABA, NPY and AgRP. Cell Metab 2013;18:588-95.

18. Jeong $\mathrm{JH}$, Lee $\mathrm{DK}$, Jo $\mathrm{YH}$. Cholinergic neurons in the dorsomedial hypothalamus regulate food intake. Mol Metab 2017;6:306-12.

19. Holland PC, Petrovich GD. A neural systems analysis of the potentiation of feding by condition edstimuli. Physiology \& Behavior 2005;86(5):747-61.

20. Robinson MJF, Warlow SM, Berridge KB. Optogenetic excitation of central amygdala amplifies and narrows Incentive motivation to pursue one reward above another. $\mathrm{J}$ Neurosci 2014;34(50):16567-80.

21. Hannapel R, Ramesh J, Ross A, et al. Post meal optogenetic inhibition of dorsalor ventral hippocampal pyramidal neurons increases future intake. eNeuro 2019;6(1):e0457-18.

22. Urstadt KR, Berridge KC. Optogenetic mapping of feding and self stimulation with in the lateral hypothalamus of therat. PLoS ONE 2020;15(1):e0224301.

23. Yang $Q$, Song D, Qing $H$. Neural changes in alzheimer's disease from circuit to molecule: perspective of optogenetics. Neurosci Biobehav Rev 2017;79:110-8.

24. Luchkina NV, Bolshakov VY. Diminishing fear: Optogenetic approach to ward understanding neural circuits of fear control. Pharmacol Biochem Behav 2017;174:64-79.

25. Ramirez S, Liu X, Lin $P$, et al. Creating a false memory in the hippocampus. Sci 2013;341(6144):387-91.

26. Pianca N, Zaglia T, Mongillo M. Will cardiac optogenetics find the way through the obscure angles of heart physiology? Biochem Biophys Res Commun 2017;482:515-23.

27. Crocini C, Ferrantini C, Pavone FS, et al. Optogenetics gets to the heart: A guiding light beyond defibrillation. Prog Biophys Mol Biol 2017;130:132-9.

28. Zhang $\mathrm{H}$, Cohen AE. Optogenetic approaches to drug discovery in neuroscience and beyond. Trends in Biotechnol 2017;35(7):625-39.

29. Ordaz JD, Wu W, Xu XM. Optogenetics and its application in neural degeneration and regeneration. Neural Regen Res 2017;12(8):1197-209.

30. Towne C, Montgomery KL, lyer SM, et al. Optogenetic control of targeted peripheral axons in freely moving animals. PLos ONE 2013;8(8):1-10. 